\title{
The Effects of Habitat Heterogeneity at Distinct Spatial Scales on Hard-Bottom-Associated Communities
}

\author{
Fabiane Gallucci ${ }^{1, *}{ }^{\mathbb{D}}$, Ronaldo A. Christofoletti ${ }^{1}{ }^{\mathbb{D}}$, Gustavo Fonseca ${ }^{1}$ and Gustavo M. Dias ${ }^{2}$ \\ 1 Institute of Marine Science, Federal University of São Paulo (IMar/UNIFESP), \\ Rua Dr. Carvalho de Mendonça 144, Santos SP 11070-100, Brazil; ronaldochristofoletti@gmail.com (R.A.C.); \\ gfonseca.unifesp@gmail.com (G.F.) \\ 2 Center of Natural and Human Sciences, Federal University of ABC (CCNH/UFABC), Rua Santa Adélia, 166, \\ Santo Andre SP 09210-170, Brazil; gmunizdias@gmail.com \\ * Correspondence: fgallucci@unifesp.br
}

Received: 30 November 2019; Accepted: 15 January 2020; Published: 20 January 2020

\begin{abstract}
For marine benthic communities, environmental heterogeneity at small spatial scales are mostly due to biologically produced habitat heterogeneity and biotic interactions, while at larger spatial scales environmental factors may prevails over biotic features. In this study, we investigated how community structure and $\beta$-diversity of hard-bottom-associated meio- and macrofauna varied in relation to small-scale $(\mathrm{cm}-\mathrm{m})$ changes in biological substrate (an algae "turf" dominated by the macroalgae Gelidium sp., the macroalgae Caulerpa racemosa and the sponge Hymeniacidon heliophile) in a rocky shore and in relation to larger-scale $\left(10^{\prime} \mathrm{s} \mathrm{m}\right)$ changes in environmental conditions of the same biological substrate (the macroalgae Bostrychia sp) in different habitats (rocky shore vs. mangrove roots). Results showed that both substrate identity and the surrounding environment were important in structuring the smaller-sized meiofauna, particularly the nematode assemblages, whereas the larger and more motile macrofauna was influenced only by larger-scale changes in the surrounding ecosystem. This implies that the macrofauna explores the environment in a larger spatial scale compared to the meiofauna, suggesting that effects of spatial heterogeneity on communities are dependent on organism size and mobility. Changes in taxa composition between environments and substrates highlight the importance of habitat diversity at different scales for maintaining the diversity of the associated fauna.
\end{abstract}

Keywords: meiofauna; macrofauna; associated fauna; biological substrate; species diversity; community ecology; benthic ecology

\section{Introduction}

In natural systems, environmental heterogeneity occurs at varying scales in space and time affecting the diversity of species. However, processes operating at one scale not necessarily scale up or down [1]. For marine benthic communities, environmental heterogeneity at small spatial scales ( $\mathrm{cm}$ to few meters) are mostly due to biologically produced habitat heterogeneity and biotic interactions, while at larger spatial scales (10's m to kilometers) environmental factors may prevails over biotic features [2]. Regardless of the mechanism behind environmental heterogeneity, it promotes species diversity by increasing the range of resources and reducing niche overlap, which in turn promotes species coexistence $[3,4]$.

In the intertidal zone of rocky shores, sessile organisms such as macroalgae and sponges increase small-scale habitat heterogeneity, harboring a diverse associated fauna [5-7]. The community structure of the associated fauna is affected by several intrinsic properties of the host, such as their physical architecture, the number of microhabitats, sediment deposition, food resources, refuge from 
predators, and wave damping effects [8-13]. In addition to this small-scale heterogeneity, variations in hydrosedimentary processes at larger scales (meters to kilometers) also affect the structure and diversity of hard-bottom-associated communities, mainly through their effects on larvae supply, dispersal and colonization of organisms [14,15].

Hard-bottom-associated fauna is usually composed by small crustaceans, nematodes, mollusks, annelids and other groups that use the host substratum as shelter and food. These organisms belong to two different ecological compartments, macrofauna and meiofauna, which are distinguished by their different size as well as different life-history traits. Besides being larger and more mobile, most macrobenthic species exhibit a planktonic larval stage so that larval dispersal can be extensive [16]. In contrast, meiofauna have direct benthic development, are smaller and exhibit lower mobility. Additionally, meiofauna is expected to be more specialized in their habitat and food resources [2,17-20], whereas macrofauna are relatively more generalist [21]. As a result, meiofauna, especially nematodes, are generally more affected by within-habitat variability when compared to larger-sized, more mobile macrofauna [16]. The latter, on the other hand, are more prone to be influenced by larger-scale environmental heterogeneity, for instance, in hydrodynamic conditions and position on the shore [22].

In this study, we aim to describe how community structure and diversity of hard-bottom-associated fauna are related to (i) small-scale $(\mathrm{cm}-\mathrm{m})$ changes in biological (secondary) substrate in a rocky shore and (ii) larger-scale (10's m) changes in environmental conditions of a same biological substrate in different habitats (rocky shore $x$ mangrove roots). At both scales, we expect habitat heterogeneity to create a mosaic that will contribute to local and regional biodiversity. As such, we have tested the hypotheses that different biological substrates harbor different associated communities (H1) and that the same biological substrate growing in different habitats harbor distinct associated communities (H2). Yet, we expect the meiofauna and macrofauna communities to respond differently to habitat heterogeneity. We expect the meiofauna communities to be more affected by within-habitat environmental variability (i.e., to show differences in composition between the biological substrates) and the macrofauna to be more influenced by larger-scale changes in environmental conditions (i.e., to show differences in species composition between the different habitats).

\section{Material and Methods}

\subsection{Study Area}

This study was conducted in the Southeastern Brazil, in the Araçá Bay (São Sebastião, SP; Figure 1). Despite the relatively small size of the bay $\left(\sim 500 \mathrm{~m}^{2}\right)$, this is a heterogeneous bay composed by rocky shores, sandy beaches, small mangrove spots and a larger soft bottom, being a hot spot of marine biodiversity [23]. The variety of different habitats in short distances makes this as a special region to test our hypothesis regarding habitat heterogeneity from smaller to larger scales. In addition to the ecological questions, our study will help to support a discussion regarding anthropogenic impacts at the bay. Araçá Bay is under the threat of the eminent expansion of the port of São Sebastião, which will cover $75 \%$ of the bay with a structure suspended by pillars, potentially reducing the occurrence of macroalgae [24], which host diverse associated fauna [25]. 


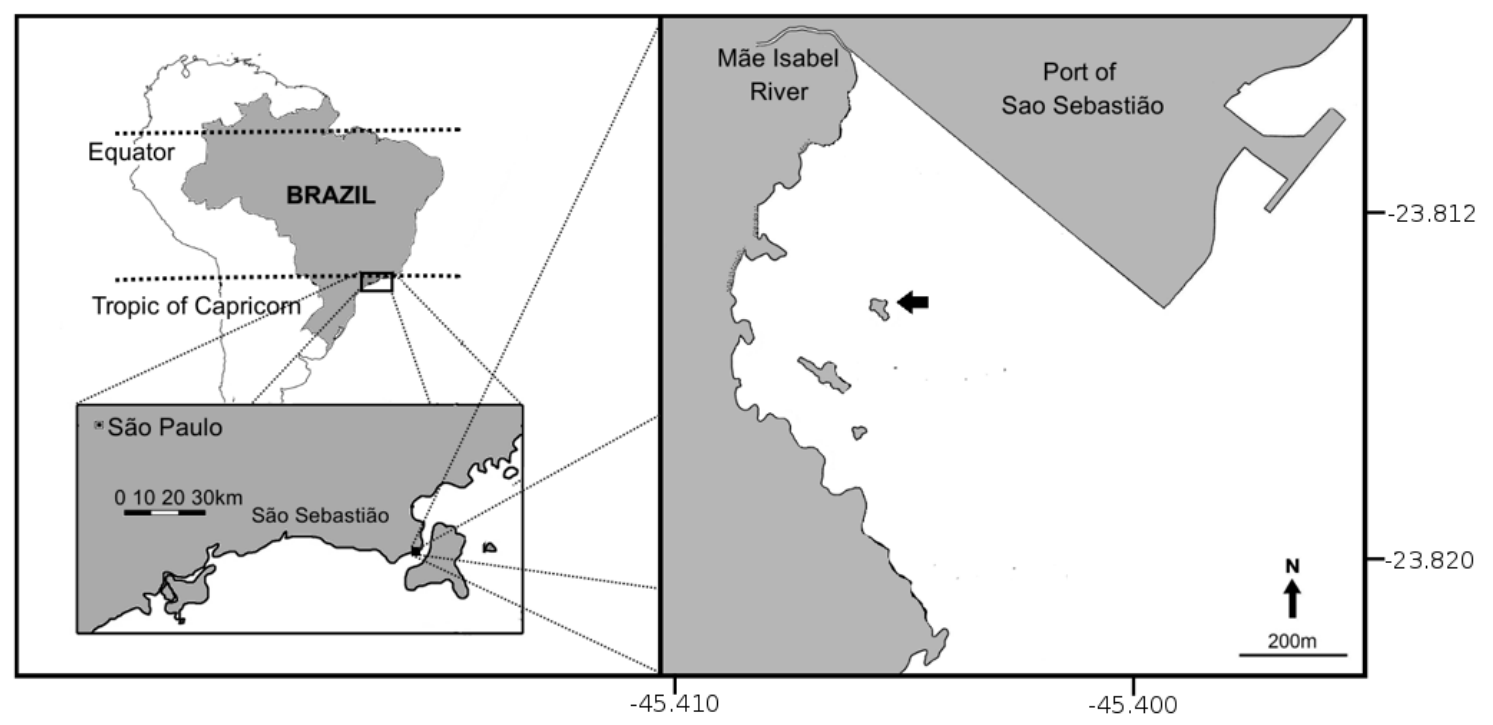

Figure 1. Map indicating the location of the Araçá Bay. The arrow indicates the sampling site.

\subsection{Experimental Design}

To test the hypothesis that different biological substrates harbor different associated communities increasing local diversity (H1) we have sampled meio- and macrofauna communities from different biological substrates growing in the intertidal zone of a rocky shore from southeastern Brazil. We decided to use the natural heterogeneity present on rocky shores so the natural substrates were (1) a "turf" of different macroalgae species ('Turf') composed mainly by algae of the genus Gelidium, (2) the macroalgae Caulerpa racemosa ('Caulerpa') and (3) the sponge Hymeniacidon heliophila ('Sponge'). While the turf substratum was homogeneous, the remaining substrata were dominated by Caulerpa and Sponges, respectively, but turfing algae were still present in abundance underneath the dominant species.

To test the hypothesis that the same biological substrate growing in different habitats harbor distinct associated communities (H2) we sampled the macroalgae Bostrychia sp. in two sites that were $20 \mathrm{~m}$ apart from each other but were structurally different: a rocky shore and the pneumatophores from the mangrove Laguncularia racemosa. In both experiments, four replicate samples were taken for each substrate.

\subsection{Sampling and Sample Processing}

Four replicate samples were taken at each substrate by scraping a quadrat $(10 \times 10 \mathrm{~cm})$ using a scraper therefore removing both the hard-bottom surface and the biological substrate. Samples from the different substrates of the rocky shore (H1) were taken within the same tidal level whereas for the comparison of the same substrate (the macroalgae Bostrychia sp.) between two different habitats $(\mathrm{H} 2)$, the tidal level was slightly different. In that case, samples from the pneumatophores from the mangrove Laguncularia racemose were taken from an upper tidal level compared to those from the rocky shore. All samples were fixed with $10 \%$ formalin and, to better detach organisms from the substrate, were sonicated for $3 \mathrm{~min}$ ( $60 \mathrm{~W}, 3$ times for $1 \mathrm{~min}$ with $30 \mathrm{~s}$ intervals) [26]. Samples were then sieved through $500 \mu \mathrm{m}$ and $45 \mu \mathrm{m}$ mesh sieves to retain macro and meiofauna, respectively. Samples were stored in $4 \%$ formalin and stained with Rose Bengal. Meiofauna were further extracted by flotation with Ludox TM 50 (specific density 1.18) [2], divided into four subsamples by using a Folsom plankton splitter. For each sample, one subsample was selected. Macrofauna and meiofauna were counted and identified under a stereomicroscope. Particularly for the meiofauna, $10 \%$ of the nematodes per subsample were randomly picked, evaporated slowly in anhydrous glycerol and mounted on permanent slides for identification. Nematodes were identified to the genus level and further separated into morphospecies. 


\subsection{Statistical Analyses}

Because the sampled substrata had distinct growth forms and consequently different biomass, the abundance of both meio- and macrofauna were pondered by the sample volume, which was measured by water dislodgment in a graduated cylinder.

Univariate and multivariate analyses were conducted on $\log (x+1)$ transformed data and presence/absence data, independently for macrofauna, meiofauna community, and for nematode assemblages, as Nematoda was the most abundant group in all samples. Abundance data was used to assess differences in community multivariate structure (including taxa composition and taxa abundances) whereas presence/absence data aimed at looking for differences in taxa composition only (i.e., turnover of taxa between the substrates for $\mathrm{H} 1$ and the habitats for $\mathrm{H} 2$ ). For each group, density, species richness and Shannon' diversity $\left(\mathrm{H}^{\prime}\right)$ were compared among substrata $(\mathrm{H} 1)$ and between habitats (H2) using one-way analyses of variance (ANOVA). Density data was $\log (x+1)$ transformed to equalize the importance of abundant and rare species and used to build a similarity matrix among samples. Differences on species composition were assessed using Sorensen distance for presence/absence, while community structure was assessed using Bray-Curtis distance for log $(x+1)$ transformed data. For both measures, differences among substrata $(\mathrm{H} 1)$ and between habitats (H2) were tested independently using Permutational analysis of variance (PERMANOVA) [27] and visually presented by a Non-metric Multidimentional Scaling ordination (NMDS). For all analyses the species that contributed the most for the differences among groups were assessed through Similarity percentage analysis (SIMPER) [28].

\section{Results}

\subsection{Different Biological Substrates Harbor Different Associated Communities}

\subsubsection{Meiofauna Community and Nematode Assemblage}

The meiofauna was represented by 13 higher taxa with mean densities ranging from 238 to 522 individual $\mathrm{mL}^{-1}$ (Table S1). Nematodes were the most abundant taxa, corresponding to $58 \%$ of all organisms collected, followed by harpacticoid copepods (20\%). Ostracods $(6 \%)$, polychaetes $(6 \%)$ and amphipods (5\%) were the next most abundant groups. Other groups represented less than $2 \%$ of the meiofauna.

Meiofauna abundance, the number of meiofaunal groups, diversity and community structure did not differ among substrates (Tables 1 and 2). However, analysis on presence/absence data revealed significant differences in the composition of meiofauna communities and nematode assemblages between the substrata (Table 2). The composition of meiofauna communities associated with the sponge was significantly different from both "Turf" and "Caulerpa" communities (post-hoc $p<0.05$, Figure 2). This difference was mainly due to the exclusive occurrence of oligochaetes in all "sponge" samples (SIMPER analysis: 36.5\% and 44.7\%, contribution for differences between "Sponge" and "Turf" and "Sponge" and "Caulerpa", respectively).

Table 1. Differences in univariate indices from macro- and meiofauna between substrates (H1) using one-way ANOVA.

\begin{tabular}{cccc}
\hline & $d f$ & $\boldsymbol{F}$ & $\boldsymbol{p}$ \\
\hline Meiofauna density & 2 & 0.079 & 0.925 \\
Nematode density & 2 & 0.513 & 0.610 \\
Number of meiofaunal taxa & 2 & 0.600 & 0.569 \\
Number of nematode species & 2 & 2.212 & 0.149 \\
Nematode diversity $\left(\mathrm{H}^{\prime}\right)$ & 2 & 2.101 & 0.162 \\
Macrofauna density & 2 & 3.055 & 0.097 \\
Number of macrofaunal taxa & 2 & 0.694 & 0.524 \\
Macrofauna diversity $\left(\mathrm{H}^{\prime}\right)$ & 2 & 2.486 & 0.138 \\
\hline
\end{tabular}


Table 2. Differences in multivariate structure of macrofauna, meiofauna and nematode assemblages between substrates using PERMANOVA. Bold values indicate $p<0.05$.

\begin{tabular}{|c|c|c|c|c|c|c|}
\hline \multirow[b]{2}{*}{ Source } & \multicolumn{3}{|c|}{ Abundance Data $(\log (x+1))$} & \multicolumn{3}{|c|}{ Presence/Absence Data } \\
\hline & $d f$ & Pseudo- $F$ & $\begin{array}{c}p(\text { perm }) \\
\text { Macrofauna }\end{array}$ & $d f$ & Pseudo-F & $p$ (perm) \\
\hline Treatment & 2 & 1.174 & 0.323 & 2 & 0.969 & 0.441 \\
\hline Residual & 9 & & & 9 & & \\
\hline & & & Meiofauna & & & \\
\hline Treatment & 2 & 1.642 & 0.115 & 2 & 5.021 & 0.003 \\
\hline Residual & 9 & & & 9 & & \\
\hline & & & Nematodes & & & \\
\hline Treatment & 2 & 1.282 & 0.212 & 2 & 2.6989 & 0.003 \\
\hline Residual & 9 & & & 9 & & \\
\hline
\end{tabular}
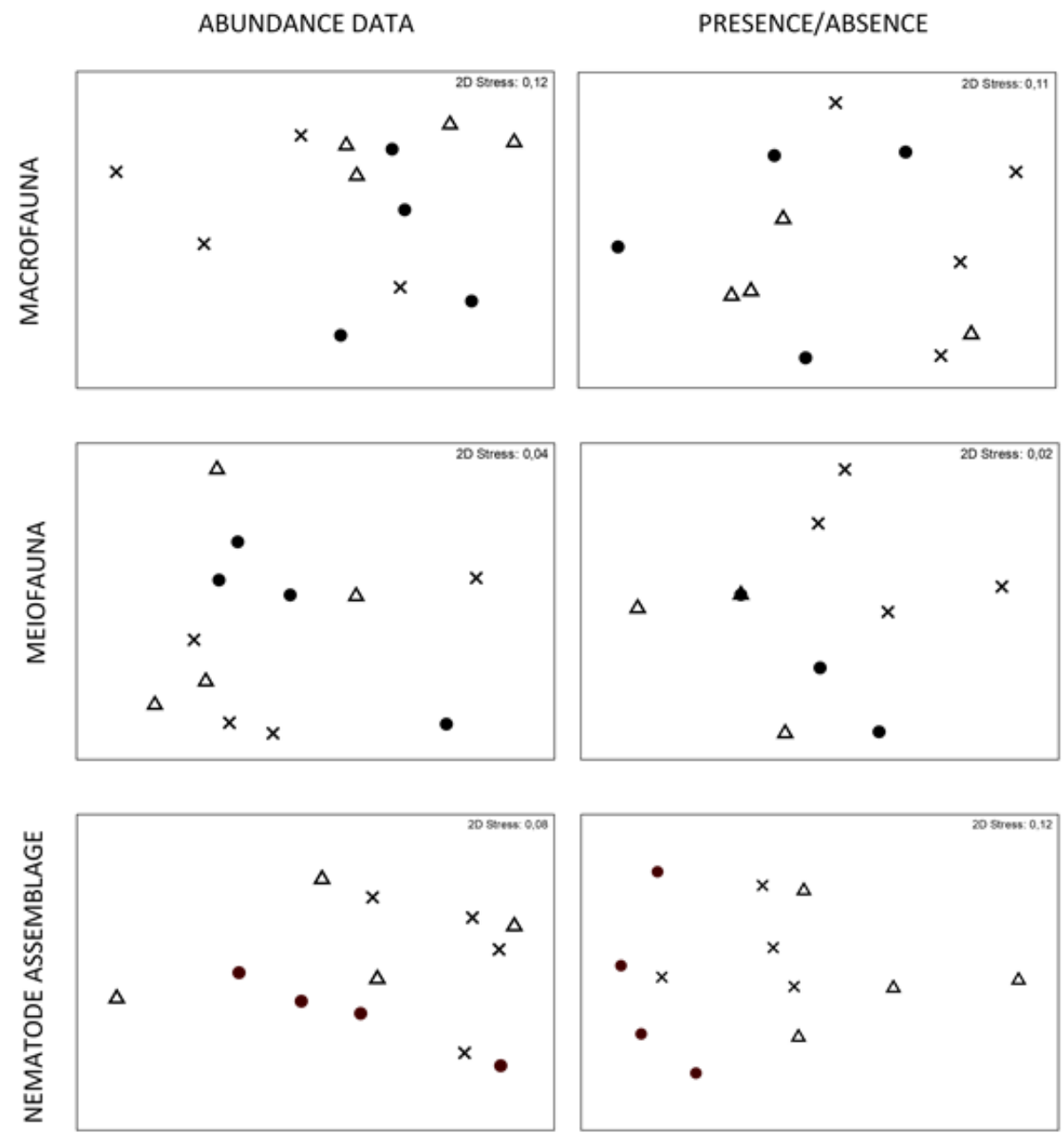

Figure 2. Non-metric multidimentional scaling (NMDS) ordination representing the similarity between samples from the substrates "Turf" $(\Delta)$, "Caulerpa" $(\bullet)$ and "Sponge" (x) for macrofauna, meiofauna and nematode assemblages.

Nematodes were represented by 56 species with densities ranging from 115 to 308 ind. $\mathrm{mL}^{-1}$ (Table S2). Spilophorella meyerabichi was the dominant species in all substrates ( $45 \%$ to $48 \%$ ). Enoplus sp.1 (5\%-9\%), Halaphanolaimus sp.1 (7\%-8\%) and Oncholaimellus sp.1 (5\%-8\%) were the next most abundant species. All other nematode species occurred in low densities, each accounting for less than $4 \%$ of the assemblage. Similarly to the meiofauna, nematode abundances, species richness, diversity and community structure did not differ among substrates (Tables 1 and 2). Analysis on presence/absence 
data, however, revealed significant differences in the species composition of nematode assemblages between "Caulerpa" and "Turf" assemblages (post-hoc $p<0.05$, Figure 2). A total of 13 species contributed to $50 \%$ of the total dissimilarity between the two substrates (Table S3). Indeed, from a total of 60 species, the different substrates shared from 22 (Caulerpa vs. Turf) to 26 species (Sponge vs. Turf) only. In addition, each substrate showed a relatively high number of exclusive species ("Caulerpa": 11 species, "Sponge": 11 species and "Turf": 7 species).

\subsubsection{Macrofauna Community}

The macrofauna was represented by 17 higher taxa with densities ranging from 56 to 303 ind. $\mathrm{mL}^{-1}$ (Table S4). The most abundant group was Gammaridae (Amphipoda), which accounted for $45 \%$ of all organisms collected, followed by Tanaidacea (20\%) and Polychaeta (17\%). All other taxa contributed with less than $2 \%$ each for the total macrofauna sampled. As for the meiofauna, macrofauna densities, number of taxa, diversity and community structure were similar in the three substrata (Table 1). However, differently from meiofauna and nematode assemblages, macrofauna composition as shown by presence/absence data did not differ between the substrata (Table 2, Figure 2).

\subsection{The Same Biological Substrate Growing in Different Habitats/Environments Harbor Different Associated Communities}

\subsubsection{Meiofauna Community and Nematodes Assemblage}

Meiofauna was represented by 16 taxa, from which 10 occurred in both environments (Table S5). Mangrove and rocky shore samples each had 3 exclusive taxa. Nematoda was the most abundant taxa, representing $73 \%$ and $62.5 \%$ of total meiofauna collected in the mangrove and rocky-shore samples, respectively. Halocaridina, Rotifera and Copepoda (adult + nauplii) were the next most abundant groups, and accounted for $6 \%, 9 \%$ and $8 \%$ in the mangrove and $19 \%, 5 \%$ and $9 \%$ in the rocky shore, respectively. Meiofauna densities did not differ between habitats (Table 3), ranging from 44 to 1278 ind. $\mathrm{mL}^{-1}$ and from 119 to 374 ind. $\mathrm{mL}^{-1}$ in the mangrove and rocky shore, respectively. The number of taxa and community structure did not differ between the two habitats either (Tables 3 and 4, Figure 3).

Nematodes were represented by 28 species with densities ranging from 15 to 982 ind. $\mathrm{mL}^{-1}$ (Table S6). Samples from the rocky shore were dominated by Araeolaimus sp.1 (35\%), followed by Eleutherolaimus sp.1 (12\%) and Microlaimus sp.1 (11\%) whereas mangrove samples were dominated by Thalassomonhystera sp.1 (46\%), followed by Araeolaimus sp.1 (19\%). Similarly to total meiofauna, nematode densities and species richness did not differ between habitats, but diversity $\left(\mathrm{H}^{\prime}\right)$ was significantly higher in the rocky shore (Table 3). Contrasting to meiofauna community, nematode assemblages from the two environments were significantly different (Table 4, Figure 3). SIMPER analysis showed that dissimilarities between rocky shore and mangrove samples (aver. dissimilarity $=54.28 \%$ ) mainly resulted from differences in abundance of a few dominant organisms (Table S7). Rocky-shore samples were characterized by higher abundances of Eleutherolaimus sp. 1 and Microlaimus sp.1, whereas mangrove samples were characterized by higher abundances of Thalassomonhystera sp.1 and Parachanthoncus sp.3. Altogether these four species accounted for $50 \%$ of dissimilarities. In addition to differences in the abundance of species, analysis on presence/absence data revealed significant differences in species composition (PERMANOVA $p=0.023$ ). A total of eight species contributed to $50 \%$ dissimilarities in species composition between the habitats (Table S8). From the 28 species associated with Bostrychia sp., only 9 species were common to both environments (Table S5). A total of 13 species were exclusive to the rocky shore whereas a total of 6 species occurred exclusively at the mangrove environment (Table S5). 
Table 3. Differences in univariate indices from macro- and meiofauna between habitat/environment (H2) using one-way ANOVA. Analysis of macro- and meiofauna densities were done on $\log (x+1)$ data.

\begin{tabular}{cccc}
\hline & $d f$ & $\boldsymbol{F}$ & $\boldsymbol{p}$ \\
\hline Meiofauna density & 1 & 0.751 & 0.419 \\
Nematode density & 1 & 0.400 & 0.550 \\
Number of meiofaunal taxa & 1 & 0.297 & 0.606 \\
Meiofauna diversity $\left(\mathrm{H}^{\prime}\right)$ & 1 & 0.128 & 0.732 \\
Number of nematode species & 1 & 3.261 & 0.121 \\
Nematode diversity (H') & 1 & 11.97 & $\mathbf{0 . 0 1 3}$ \\
Macrofauna density & 1 & 0.235 & 0.645 \\
Number of macrofaunal taxa & 1 & 25.00 & $\mathbf{0 . 0 0 2}$ \\
Macrofauna diversity $\left(\mathrm{H}^{\prime}\right)$ & 1 & 53.50 & $<\mathbf{0 . 0 0 1}$ \\
\hline
\end{tabular}

Table 4. Differences in multivariate structure of macrofauna, meiofauna and nematode assemblages from the different environments using one-way PERMANOVA. Data were $\log (\mathrm{x}+1)$ transformed. Bold values indicate $p<0.05$.

\begin{tabular}{|c|c|c|c|}
\hline Source & $d f$ & Pseudo-F & $p($ perm $)$ \\
\hline \multicolumn{4}{|c|}{ Macrofauna } \\
\hline Treatment & 1 & 5.2506 & 0.026 \\
\hline Residual & 6 & & \\
\hline \multicolumn{4}{|c|}{ Meiofauna } \\
\hline Treatment & 1 & 2.3293 & 0.125 \\
\hline Residual & 6 & & \\
\hline \multicolumn{4}{|c|}{ Nematodes } \\
\hline Treatment & 1 & 3.7215 & 0.032 \\
\hline Residual & 6 & & \\
\hline
\end{tabular}

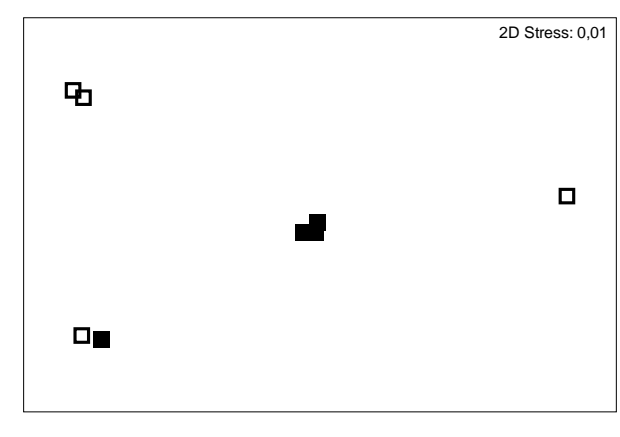

Meiofauna

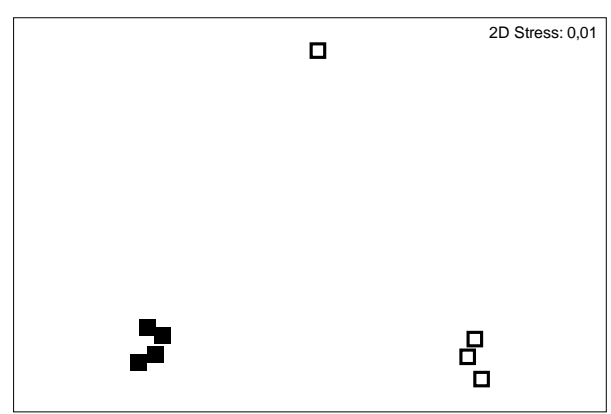

Nematode assemblage

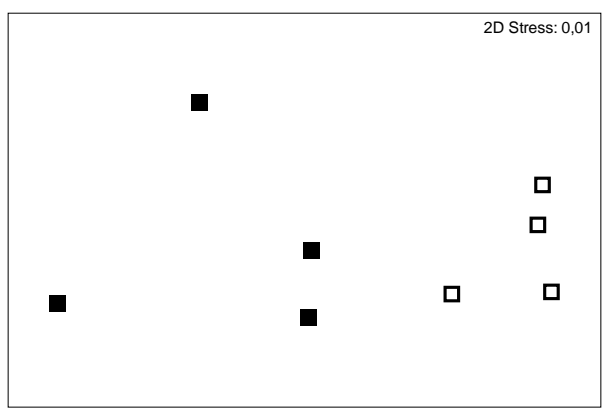

Macrofauna

Figure 3. MDS ordination representing the similarity between samples from Bostrychia sp. from the rocky shore $(\mathbf{\square})$ and mangrove roots $(\square)$. Data were $\log (x+1)$ transformed. 


\subsubsection{Macrofauna Community}

Macrofauna associated with Bostrychia sp. was represented by 13 taxa, from which 9 were exclusive to the rocky shore and only 4 , which were also present in the rocky shore, occurred in mangrove samples (Table S9). In both environments, Chironomidae and Tanaidacea were the most abundant groups. However, whereas in the rocky shore they accounted for $49.5 \%$ of the total macrofauna, in the mangrove the two groups represented $98 \%$ of all organisms collected.

Total macrofauna densities did not differ between habitats (Table 3) ranging from 5 to 7 and from 2.75 to 9.5 ind. $\mathrm{mL}^{-1}$ in the rocky-shore and mangrove samples, respectively. The average number of taxa per sample was significantly lower in the mangrove (2-4 taxonomic groups) than in the rocky-shores communities (5-9 taxonomic groups) (Table 3). Accordingly, diversity was also higher in the rocky shore (Table 3). The difference in species richness and composition resulted in distinct macrofauna communities in the two habitats (Table 4, Figure 3). This difference was mainly due to the absence of Cirripedia, Collembola and Bivalvia and the higher abundances of Chironomidae and Tanaidacea in mangrove samples (SIMPER analyses, Table S10).

\section{Discussion}

Habitat complexity mediates species coexistence increasing diversity in several communities [29-35]. Here, complexity generated by the biogenic structures and by the surrounding environment creates heterogeneous habitats that support a diverse associated fauna. However, the scale in which environmental changes affected the fauna depended, as expected, on the benthic component analyzed. While the small-sized meiofauna were affected by heterogeneity at both scales, the larger and more mobile macrofauna was unaffected by heterogeneity within habitat but responded to larger-scale differences in the structure of the studied habitats (rocky shore and mangroves).

The influence of biogenic small-scale habitat heterogeneity for meiofauna community structure is well documented for soft sediment environments [36-39]. Evidences for communities from hard-bottom substrates however are limited but corroborate the importance of the complexity for diversity. Meiofauna species from phytal communities are known to be host-specific [40-43] and the increase in algae morphotypes results in a diversified meiofaunal community. Biological substrates can influence the composition and structure of the associated fauna by its architecture [8], the amount of sediment accumulated on it [12,44], the protection it offers against predators [13,45], shelter from extreme physical condition [46,47] and the provision of food resources [10]. In the current study, sponge communities were differentiated by the occurrence of meiofaunal oligochaetes, which are ectocommensals of sponges [48,49]. Oligochaetes inhabiting such filter-feeding organisms benefit from being in an environment with intense water flowing, ensuring high oxygen availability and food (microorganisms and organic detritus), and a lower exposure to the variable conditions of free sediments [48]. In contrast, nematode assemblages associated with sponges did not differ from the other substrates but showed a high turnover of species between "Turf" and "Algae". The species that contributed to the differences occurred in very low densities hampering any conclusion of host association. However, the "Turf" environment creates an intricate mesh of filaments that accumulates much more sediment when compared to the "Algae" environment, probably influencing species abundances and composition. Given the different macroalgal morphologies, it is also possible that differences in irradiance and temperature between the two substrates, especially at daytime and low tide [47], might have played a role. Although the mechanism is not clear, the habitat heterogeneity created by the substrates had an important role in favoring the occurrence of rare species therefore maintaining the regional diversity.

Contrary to the meiofauna and nematode assemblages, differences in substrata identity did not affect macrofauna community therefore agreeing with our expectation, i.e., the meiofauna was more influenced by the smaller-scale heterogeneity investigated in this study than the macrofauna. These results suggest that the larger and relatively more motile macrofauna can possibly move through all studied substrates within habitats and the small-scale variations of environmental conditions offered 
by the different substrates did not represent contrasting selective pressures for this group. Similar observations were reported for macrofauna inhabiting different type and morphology of sponges [50]. It is possible though that any eventual small-scale variation among biological substrata within the studied zone of the rocky shore is species-specific, so our analyses conducted at lower taxonomic resolution may have prevented us to observe species-specific differences among communities. However, in a region close to our study site, the structure of amphipod assemblages analyzed to the specific level was not affected by algae identity and architecture, but only by its position through the intertidal zone [51]. Even hosts with very distinct architecture, when occurring in the same position of the shore, supported similar associated communities [51]. These findings suggest that factors controlling community assembly of macrofaunal organisms may operate on a wider scale.

Accordingly, the primary substrate and/or the surrounding environment where this occurred influenced both the nematode assemblages and macrofauna. Fauna associated to the same substratum, but under different environmental conditions, are often distinct [52] because hosts do not necessary buffer the distinct selective pressures to which associated fauna is exposed. Mangrove samples were characterized by higher abundances of Thalassomonhystera sp.1, which is a genus frequently found in mangrove sediments and mangrove litter (e.g., [53,54], probably as a consequence of both the higher proximity to the sediment and the higher sedimentation in the Bostrichetum communities from mangrove roots. In addition, there was a significant overlap in species composition between the two habitats and the number of shared species was relatively low $(32 \%)$ suggesting that the surrounding environment was highly selective. For the macrofauna, the longer exposure to air to which associated fauna is exposed in mangroves restricted the occurrence of marine groups as Cirripedia, Collembola and Bivalvia reducing diversity, but facilitated the occurrence of typically terrestrial organisms such as Chironomidae larvae. While we did not address the mechanism behind the absence of typically marine species in mangrove habitats, the longer exposure to air can restrict the access of reproductive propagules, but also increase post-recruitment mortality, which probably caused the differences observed here. Differences in taxonomic composition of the associate fauna from the same secondary substrate in different habitats were also observed for fauna associated with mussel beds growing on soft vs. hard substrates [52]. While it has been suggested that changes in wave exposure and the proportion of faeces and pseudo-faeces of mussels deposited within the mussels bed would explain such differences [52]; here we suggest that changes in environmental conditions as distance to the soft-bottom, the amount of sediment deposited over the secondary substrate and aerial exposure would influence the differences in the associated fauna between macroalgae on rocky shores vs. mangrove environments.

\section{Conclusions}

Changes in species composition between environments and substrates highlight the importance of habitat diversity at different scales in maintaining the diversity of the associated fauna. In addition, whereas both substrate identity and the surrounding environment were important in structuring the smaller-sized meiofauna, the macrofauna was more influenced by larger-scale changes in the surrounding ecosystem. This implies that the larger and more motile macrofauna explores the environment in a larger spatial scale compared to the meiofauna, which are smaller and more sedentary (therefore restricted to a smaller space), suggesting that effects of spatial heterogeneity on communities are dependent on organism size and mobility. Besides, species turnover occurred mainly regarding species with low abundances (i.e., rare species). These results stress the importance of considering the rarer groups in ecological studies and/or impact assessments on local and regional diversity. It is important to note, however, that because our study is limited to a single sampling location, the generalizations of our findings must be further tested in other habitat types and regions. Also, because of the frequency of occurrence and abundance of rare species might change as a function of sampling effort, different rarity patterns could emerge if more samples were taken. 
Considering the eminent expansion of the harbor over rocky shores and mangroves from the Araçá Bay and the effects of artificial substrate construction and shading, leading to large modifications on biological substrates on rocky shores [24,55], the anthropogenic impact in the area has the potential to promote large changes to both meiofauna and macrofauna biodiversity in the area. Because both macro- and meiofauna biodiversity are positively related to important ecosystem processes [56,57], such effects can potentially go beyond structural changes in biodiversity and are likely to translate into major impacts to ecosystem functioning.

Supplementary Materials: The following are available online at http://www.mdpi.com/1424-2818/12/1/39/s1, Table S1: Mean density (inds. $\mathrm{ml}^{-1}$ ) and standard deviation (in parenthesis) of meiofauna higher taxa in the different biological substrates sampled in a rocky-shore from Araçá Bay, Southeast Brazil; Table S2: Mean density (inds. $\mathrm{mL}^{-1}$ ) and standard deviation (in parenthesis) of nematode morphospecies in the different biological substrates sampled in a rocky shore from Araçá Bay, Southeast Brazil; Table S3: Mean density (inds. $\mathrm{mL}^{-1}$ ) and standard deviation (in parenthesis) of macrofauna higher taxa in the different biological substrates sampled in a rocky shore from Araçá Bay, Southeast Brazil; Table S4: Mean density (inds. $\mathrm{mL}^{-1}$ ) and standard deviation (in parenthesis) of meiofauna higher taxa associated with Bostrychia sp. sampled from the rocky shore habitats and mangrove roots at Araçá Bay, Southeast Brazil; Table S5: Mean density (inds. $\mathrm{mL}^{-1}$ ) and standard deviation (in parenthesis) of nematode species associated with Bostrychia sp. sampled from the rocky shore habitats and mangrove roots at Araçá Bay, Southeast Brazil; Table S6: Mean density (inds. $\mathrm{mL}^{-1}$ ) and standard deviation (in parenthesis) of macrofauna taxa associated with Bostrychia sp. sampled from the rocky shore habitats and mangrove roots at Araçá Bay, Southeast Brazil; Table S7: SIMPER analysis showing nematode species ranked according to average Sorensen dissimilarity from presence/absence data between the biological substrates 'Caulerpa' and 'Turf'; Table S8: SIMPER analysis showing nematode species ranked according to average Bray-Curtis dissimilarity from log $(x+1)$ data between the rocky shore habitats and mangrove roots; Table S9: SIMPER analysis showing nematode species ranked according to average Bray-Curtis dissimilarity from $\log (x+1)$ data between the rocky shore habitats and mangrove roots; Table S10: SIMPER analysis showing macrofauna groups ranked according to average Bray-Curtis dissimilarity from $\log (x+1)$ data between the rocky shore habitats and mangrove roots.

Author Contributions: All authors have equally contributed to the conceptualization of the idea and the methods used. Data acquisition (sampling and samples processing) were coordinated by G.M.D., R.A.C., G.F. and F.G. had conducted statistical analysis and data interpretation was done by all authors. F.G. prepared the original draft with considerable contributions from G.M.D. All authors have substantially contributed to the writing of the final text. All authors have read and agreed to the published version of the manuscript.

Funding: This research was supported by research funds granted by São Paulo Research Foundation (FAPESP) to Biota Araçá Project (\#2011/50317-5). We thank Felipe Dutra and Viviane Gomes for support with field and laboratory work. We are very grateful to Antônia Cecília Zacagnini Amaral, who acquired funding and wisely administrated the Biota Araçá Project, for this opportunity.

Conflicts of Interest: The authors declare no conflicts of interest. The sponsors had no role in the design, execution, interpretation, or writing of the study.

\section{References}

1. Hewitt, J.E.; Thrush, S.F.; Dayton, P.K.; Bonsdorff, E. The effect of spatial and temporal heterogeneity on the design and analysis of empirical studies of scale-dependent systems. Am. Nat. 2007, 169, 398-408. [CrossRef] [PubMed]

2. Moens, T.; Braeckman, U.; Derycke, S.; Fonseca, G.; Gallucci, F.; Gingold, R.; Guilini, K.; Ingels, J.; Leduc, D.; Vanaverbeke, J.; et al. Ecology of free-living marine nematodes. In Nematoda; DE GRUYTER: Berlin, Germany, 2013.

3. Downes, B.J.; Lake, P.S.; Schreiber, E.S.G.; Glaister, A. Habitat Structure and Regulation of Local Species Diversity in a Stony, Upland Stream. Ecol. Monogr. 1998, 68, 237. [CrossRef]

4. Chesson, P.; Rosenzweig, M. Behavior, Heterogeneity, and the Dynamics of Interacting Species. Ecology 1991, 72, 1187-1195. [CrossRef]

5. Christie, H.; Norderhaug, K.; Fredriksen, S. Macrophytes as habitat for fauna. Mar. Ecol. Prog. Ser. 2009, 396, 221-233. [CrossRef]

6. Kelaher, B. Influence of physical characteristics of coralline turf on associated macrofaunal assemblages. Mar. Ecol. Prog. Ser. 2002, 232, 141-148. [CrossRef]

7. Moreno, T.R.; da Rocha, R.M. Associated Fauna with Eudistoma Carolinense (Tunicata, Ascidiacea) Compared with other Biological Substrates with Different Architectures. J. Coast. Res. 2006, 39, 1695-1699. 
8. Chemello, R.; Milazzo, M. Effect of algal architecture on associated fauna: Some evidence from phytal molluscs. Mar. Biol. 2002, 140, 981-990.

9. Coull, B.C.; Wells, J.B.J. Refuges from Fish Predation: Experiments with Phytal Meiofauna from the New Zealand Rocky Intertidal. Ecology 1983, 64, 1599-1609. [CrossRef]

10. Duffy, J.E.; Hay, M.E. Strong Impacts of Grazing Amphipods on the Organization of a Benthic Community. Ecol. Monogr. 2000, 70, 237. [CrossRef]

11. Gibbons, M.J. Impact of predation by juvenile Clinus superciliosus on phytal meiofauna: Are fish important as predators? Mar. Ecol. Prog. Ser. 1988, 45, 13-22. [CrossRef]

12. Hicks, G.R.F. Structure of phytal harpacticoid copepod assemblages and the influence of habitat complexity and turbidity. J. Exp. Mar. Biol. Ecol. 1980, 44, 157-192. [CrossRef]

13. Martin-Smith, K.M. Abundance of mobile epifauna: The role of habitat complexity and predation by fishes. J. Exp. Mar. Biol. Ecol. 1993, 174, 243-260. [CrossRef]

14. Thiébaut, E.; Cabioch, L.; Dauvin, J.-C.; Retiere, C.; Gentil, F. Spatio-Temporal Persistence of the Abra Alba-Pectinaria Koreni Muddy-Fine Sand Community of the Eastern Bay of Seine. J. Mar. Biol. Assoc. UK 1997, 77, 1165-1185. [CrossRef]

15. Van Hoey, G.; Vincx, M.; Degraer, S. Temporal variability in the Abra alba community determined by global and local events. J. Sea Res. 2007, 58, 144-155. [CrossRef]

16. Schratzberger, M.; Maxwell, T.A.D.; Warr, K.; Ellis, J.R.; Rogers, S.I. Spatial variability of infaunal nematode and polychaete assemblages in two muddy subtidal habitats. Mar. Biol. 2008, 153, 621-642. [CrossRef]

17. Lebreton, B.; Richard, P.; Galois, R.; Radenac, G.; Brahmia, A.; Colli, G.; Grouazel, M.; André, C.; Guillou, G.; Blanchard, G.F. Food sources used by sediment meiofauna in an intertidal Zostera noltii seagrass bed: A seasonal stable isotope study. Mar. Biol. 2012, 159, 1537-1550. [CrossRef]

18. Moens, T.; Verbeeck, L.; de Maeyer, A.; Swings, J.; Vincx, M. Selective attraction of marine bacterivorous nematodes to their bacterial food. Mar. Ecol. Prog. Ser. 1999, 176, 165-178. [CrossRef]

19. Gallucci, F.; Steyaert, M.; Moens, T. Can field distributions of marine predacious nematodes be explained by sediment constraints on their foraging success? Mar. Ecol. Prog. Ser. 2005, 304, 167-178. [CrossRef]

20. Vafeiadou, A.-M.; Materatski, P.; Adão, H.; de Troch, M.; Moens, T. Resource utilization and trophic position of nematodes and harpacticoid copepods in and adjacent to Zostera noltii beds. Biogeosciences 2014, 11, 4001-4014. [CrossRef]

21. Species Size Distributions in Marine Benthic Communities on JSTOR. Available online: https://www.jstor. org/stable/4217200?seq=1\#metadata_info_tab_contents (accessed on 29 November 2019).

22. Eckman, J.E. Hydrodynamic processes affecting benthic recruitment1. Limnol. Oceanogr. 1983, 28, $241-257$. [CrossRef]

23. Amaral, A.C.Z.; Ciotti, A.M.; Fonseca, G. Biodiversity and functioning of a subtropical coastal ecosystem: Subsidies for integrated management. Ocean Coast. Manag. 2018, 164, 1-3. [CrossRef]

24. Pardal-Souza, A.L.; Dias, G.M.; Jenkins, S.R.; Ciotti, Á.M.; Christofoletti, R.A. Shading impacts by coastal infrastructure on biological communities from subtropical rocky shores. J. Appl. Ecol. 2017, 54, 826-835. [CrossRef]

25. Vieira, E.A.; Filgueiras, H.R.; Bueno, M.; Leite, F.P.P.; Dias, G.M. Algas co-ocorrentes e morfologicamente distintas suportam uma diversa fauna associada na zona entremarés na baía do araçá, Brasil. Biota Neotrop. 2018, 18. [CrossRef]

26. Danovaro, R.; Fraschetti, S. Meiofaunal vertical zonation on hard-bottoms: Comparison with soft-bottom meiofauna. Mar. Ecol. Prog. Ser. 2002, 230, 159-169. [CrossRef]

27. Anderson, M.J. A new method for non-parametric multivariate analysis of variance. Austral Ecol. 2001, 26, 32-46.

28. Clarke, K.R. Non-parametric multivariate analyses of changes in community structure. Austral Ecol. 1993, 18, 117-143. [CrossRef]

29. Taniguchi, H.; Tokeshi, M. Effects of habitat complexity on benthic assemblages in a variable environment. Freshw. Biol. 2004, 49, 1164-1178. [CrossRef]

30. Gratwicke, B.; Speight, M.R. The relationship between fish species richness, abundance and habitat complexity in a range of shallow tropical marine habitats. J. Fish Biol. 2005, 66, 650-667. [CrossRef] 
31. Sueiro, M.C.; Bortolus, A.; Schwindt, E. Habitat complexity and community composition: Relationships between different ecosystem engineers and the associated macroinvertebrate assemblages. Helgol. Mar. Res. 2011, 65, 467-477. [CrossRef]

32. Willis, S.C.; Winemiller, K.O.; Lopez-Fernandez, H. Habitat structural complexity and morphological diversity of fish assemblages in a Neotropical floodplain river. Oecologia 2005, 142, 284-295. [CrossRef]

33. St. Pierre, J.I.; Kovalenko, K.E. Effect of habitat complexity attributes on species richness. Ecosphere 2014, 5, art22. [CrossRef]

34. Hauser, A.; Attrill, M.J.; Cotton, P.A. Effects of habitat complexity on the diversity and abundance of macrofauna colonising artificial kelp holdfasts. Mar. Ecol. Prog. Ser. 2006, 325, 93-100. [CrossRef]

35. Öster, M.; Cousins, S.A.O.; Eriksson, O. Size and heterogeneity rather than landscape context determine plant species richness in semi-natural grasslands. J. Veg. Sci. 2007, 18, 859-868. [CrossRef]

36. Passarelli, C.; Olivier, F.; Paterson, D.; Hubas, C. Impacts of biogenic structures on benthic assemblages: Microbes, meiofauna, macrofauna and related ecosystem functions. Mar. Ecol. Prog. Ser. 2012, 465, 85-97. [CrossRef]

37. Reise, K. High abundance of small zoobenthos around biogenic structures in tidal sediments of the Wadden Sea. Helgoländer Meeresunters. 1981, 34, 413-425. [CrossRef]

38. Hasemann, C.; Soltwedel, T. Small-Scale Heterogeneity in Deep-Sea Nematode Communities around Biogenic Structures. PLoS ONE 2011, 6, e29152. [CrossRef]

39. Bell, S.S.; Watzin, M.C.; Coull, B.C. Biogenic structure and its effect on the spatial heterogeneity of meiofauna in a salt marsh. J. Exp. Mar. Biol. Ecol. 1978, 35, 99-107. [CrossRef]

40. Veiga, P.; Sousa-Pinto, I.; Rubal, M. Meiofaunal assemblages associated with native and non-indigenous macroalgae. Cont. Shelf Res. 2016, 123, 1-8. [CrossRef]

41. Trotter, D.B.; Webster, J.M. Feeding preferences and seasonality of free-living marine nematodes inhabiting the kelp Macrocystis integrifolia. Mar. Ecol. Prog. Ser. 1984, 14, 151-157. [CrossRef]

42. Frame, K.; Hunt, G.; Roy, K. Intertidal meiofaunal biodiversity with respect to different algal habitats: A test using phytal ostracodes from Southern California. Hydrobiologia 2007, 586, 331-342. [CrossRef]

43. Hicks, G.R.F. Observations on substrate preference of marine phytal harpacticoids (copepoda). Hydrobiologia 1977, 56, 7-9. [CrossRef]

44. Gibbons, M.J. The impact of sediment accumulations, relative habitat complexity and elevation on rocky shore meiofauna. J. Exp. Mar. Biol. Ecol. 1988, 122, 225-241. [CrossRef]

45. Russo, A.R. Role of habitat complexity in mediating predation by the gray damselfish Abudefduf sordidus on epiphytal amphipods. Mar. Ecol. Prog. Ser. 1987, 36, 101-105. [CrossRef]

46. Watt, C.A.; Scrosati, R.A. Bioengineer effects on understory species richness, diversity, and composition change along an environmental stress gradient: Experimental and mensurative evidence. Estuar. Coast. Shelf Sci. 2013, 123, 10-18. [CrossRef]

47. Umanzor, S.; Ladah, L.; Calderon-Aguilera, L.E.; Zertuche-González, J.A. Intertidal macroalgae influence macroinvertebrate distribution across stress scenarios. Mar. Ecol. Prog. Ser. 2017, 584, 67-77. [CrossRef]

48. De Ronde, C.E.J.; Stoffers, P.; Garbe-Schönberg, D.; Christenson, B.W.; Jones, B.; Manconi, R.; Browne, P.R.L.; Hissmann, K.; Botz, R.; Davy, B.W.; et al. Discovery of active hydrothermal venting in Lake Taupo, New Zealand. J. Volcanol. Geotherm. Res. 2002, 115, 257-275. [CrossRef]

49. Rota, E.; Manconi, R. Taxonomy and Ecology of Sponge-Associate Marionina spp. (Clitellata: Enchytraeidae) from the Horomatangi Geothermal System of Lake Taupo, New Zealand. Int. Rev. Hydrobiol. 2004, 89, 58-67. [CrossRef]

50. Ávila, E.; Ortega-Bastida, A.L. Influence of habitat and host morphology on macrofaunal assemblages associated with the sponge Halichondria melanadocia in an estuarine system of the southern Gulf of Mexico. Mar. Ecol. 2015, 36, 1345-1353. [CrossRef]

51. Bueno, M.; Dias, G.M.; Leite, F.P.P. The importance of shore height and host identity for amphipod assemblages. Mar. Biol. Res. 2017, 13, 870-877. [CrossRef]

52. Thiel, M.; Ullrich, N. Hard rock versus soft bottom: The fauna associated with intertidal mussel beds on hard bottoms along the coast of Chile, and considerations on the functional role of mussel beds. Helgol. Mar. Res. 2002, 56, 21-30. [CrossRef]

53. Gagarin, V.G.; Thanh, N.V. Four new species of monhysterids (Nematoda: Monhysterida) from mangroves of the Mekong river estuaries of Vietnam. TAP CHI SINH HOC 2014, 30, 16-25. [CrossRef] 
54. Brustolin, M.C.; Nagelkerken, I.; Fonseca, G. Large-scale distribution patterns of mangrove nematodes: A global meta-analysis. Ecol. Evol. 2018, 8, 4734-4742. [CrossRef] [PubMed]

55. Malerba, M.E.; White, C.R.; Marshall, D.J. The outsized trophic footprint of marine urbanization. Front. Ecol. Environ. 2019, 17, 400-406. [CrossRef]

56. Schratzberger, M.; Ingels, J. Meiofauna matters: The roles of meiofauna in benthic ecosystems. J. Exp. Mar. Biol. Ecol. 2018, 502, 12-25. [CrossRef]

57. Belley, R.; Snelgrove, P.V.R. Relative contributions of biodiversity and environment to benthic ecosystem functioning. Front. Mar. Sci. 2016, 3, 242. [CrossRef]

(C) 2020 by the authors. Licensee MDPI, Basel, Switzerland. This article is an open access article distributed under the terms and conditions of the Creative Commons Attribution (CC BY) license (http://creativecommons.org/licenses/by/4.0/). 